\title{
Dead or Dormant? Docile or Fractured? The Culture of Military Clampdown on Youth Demonstrations and its Repercussions on the $21^{\text {ST }}$ Century Nigerian Youths
}

\author{
Charles E. Ekpo \\ Institute for Peace and Strategic Studies, University of Ibadan, Nigeria \\ Cletus A. Agorye \\ History \& International Studies, University of Calabar, Nigeria
}

\begin{abstract}
The history of military regimes in Nigeria is synonymous with the history of suppression, repression, extricable use of violence, impunity and blatant trampling on fundamental human rights. Exclusive of J. T. U. Ironsi's short six months in office, every military dictator in Nigeria had propelled himself to the rein through dubious and anti-people means. It was therefore not fortuitous that these praetorian guards, possessing the powers of 'life and death', trampled on, subdued, and caged the 'bloody civilians' whose social contract they had successfully usurped. Being the most affected, Nigerian youths had in several scenarios, occasions and events staged protests, demonstrations and marches to register their discontentment and resentment towards the military dictatorships. The reactions from the military governments were always violent, brutal, dreadful and aptly horrific. Military regimes went extra miles to enforce authority, legitimacy and acceptability. Whether through killing, maiming, blackmailing, bribing or threats, the youths had to be forced or cajoled into submission. This work focuses on military clampdown on youth demonstrations during the military era. It argues that the various repressive regimes had nurtured a docile and sycophantic youths who either display lackadaisical attitude over issues bothering social contract or are ignorant and nonchalant about governance in the country. Secondary evidences are used in the analysis.
\end{abstract}

Keywords: Military rule, youth demonstrations, political consciousness, social contract, youth docility, Military Coups and Interventions 


\section{Introduction: A History of Military Intervention in Nigeria's Politics}

The military in every state is supposed to be that unit whose specialty resides on the monopoly of violence utilized in protecting a nation when called upon to do so. A military officer is supposed to be professional "obedient and loyal to the authority of the state, competent in military expertise, dedicated to using his skills to provide for the security of the state, and politically and morally neutral" (Huntington, 1957:52).

The contrary was to be the case in Nigeria, as the British instructors of the 'infant' Nigerian army were rushed out of the country behind a volatile army corps. Upon the departure of Major-General Christopher Earle WelbyEverard, the 'Nigerianization' of the Nigerian army was completed. Yet, the army corps was nothing but a miniature of a political party; a seeming time bomb. As rightly observed by Siollun (2009:27), the army corps became politicized due to the "introduction into the army of university graduates, the politicians' unwise meddling in army affairs, and the government's use of the army to solve political crisis created by it".

Nigeria, upon her independence in 1960 toed the democratic path along the British Westminster structures. While Sir Abubakar Tafawa Balewa emerged as the Prime Minister, Dr. Nnamdi Azikiwe clinched the position of the pioneer president of the young nation. Military unprofessionalism manifested when some hotheaded youths of the Nigerian military attempted a coup on the eve of January 15, 1966; leaving the country in disarray by dawn. Casualties of the failed coup included the Prime Minister, Alhaji Tafawa Balewa, the Sarduana of Sokoto, Alhaji Ahmadu Bello, the Prime Minister of Western Nigeria, Chief Samuel Akintola, the Federal Finance Minister, Chief Festus S. Okotie Eboh and high ranking military officers namely: Brigadiers S. A. Ademulegun and Z. Maimalari, Colonels Kur Mohammed, Ralph A. Shodeinde, Lt. Colonels James Pam, Arthur Unegbe and Abogo Largema (Undiyaundeye, 2011). The January 15, 1966 attempted coup was the ultimate result of the governance crisis that characterized the first republic's brief rule. Essential among the key issues included the muted confrontation between the President and the Prime Minister arising from the 1964 federal elections and the rigged western regional elections of 1965 that resulted in the breakdown of law and order in the region. The attempted coup was perceived to be 'Igbo coup' because a chunk of the coup casualties were either northerners or south westerners (Aiyede, 2015:100). A unanimous decision by all power blocs in the country assented to a brief military intervention to be led by the GOC Major-Gen. Ironsi so normalcy could be restored.

Upon assumption of office, Major-Gen. Ironsi suspended the constitution, promulgated the Unification Decree (Decree 34), failed to try and even continued the payment of salaries of the perpetrators of the January attempted coup. This provoked the north, created ethnic tensions and incited 
the fear of an "Igbo planet". The resentment on the Ironsi's regime by northern soldiers culminated in the infamous Abeokuta mutiny of July 28, 1966 which climaxed in the brutal killing of Major-Gen. Aguyi Ironsi and the subsequent assumption of power by Lt. Colonel Yakubu Gowon amidst superior officers such as Brigadier Ogundipe, Commodore Wey and Colonel Robert Adebayo (Siollun, 2011). With the July 1966 mutiny, the cohesion of the army under a single command was lost and further deteriorated when Lt. Colonel Ojukwu objected to the ascension of Lt. Colonel Gowon as Head of State because the later was not the next in command after Major-Gen. Ironsi. Attempts at resolving the conflict attained a deadlock with the conflict escalating into a civil war in 1967. The Ojukwu led secessionist Independent Republic of Biafra was defeated and reincorporated into the Federal Republic of Nigeria by 1970 (Aiyede, 2015); Gowon had thus consolidated his rule.

The Gowon's regime failure to hand over power to the civilians caused disaffection and was subsequently overthrown through a bloodless coup in the early hours of July 29, 1975 with General Murtala Muhammed replacing him as the Head of State. Murtala Muhammed carried out radical reforms, bizarre promotions, excluded some senior officers in the armed forces echelons from the Supreme Military Council (SMC) and paid little or no attention to his personal security. One day to the 1976 Valentine's Day, Muhammed was murdered by a group of coup plotters led by Lt. Colonel Dimka. This abortive action propelled Mohammed's Second in Command Lt. General Olusegun Obasanjo to the position of the Head of State. Lt. Gen. Obasanjo trailed Mohammed's policies and successfully handed over power to the civilian government of Alhaji Shehu Shagari in 1979.

The short puncture of military rule by the civilians was further truncated in December 31, 1983 when the military again struck, replacing President Shagari with Major-Gen. Muhammadu Buhari. Buhari's regime did not last long for some obvious reasons, including intra-class struggle within the military echelon. Accordingly, another coup in August 27, 1985 replaced General Buhari with General Ibrahim Babangida.

Babangida ran the nation's economy aground, implemented the poorly timed structural adjustment programme (SAP) and annulled the June 12, 1993 elections popularly believed to have been won by the late Chief M. K. O. Abiola. The agitations, protests and demonstrations against these policies mounted pressures on 'President' Babangida, leading to his 'stepping aside' with Ernest Shonekon as head of an interim government on August 17, 1993 (Siollun, 2013). The interim government having been declared illegal by a court of law was sacked weeks after by General Sanni Abacha through a bloodless coup. General Abacha demolished all existing democratic structures and began fresh plans to succeed himself as a civilian president. His plans were frustrated as he died cryptically in June 8, 1998. Abacha was succeeded 
by another military junta General Abdulsalami Abubakar who swiftly worked out modalities for, and transferred power to the civilians in May 29, 1999 (Aiyede, 2015). So far so good, the civilians have perpetually ruled for about seventeen years without interruption.

\section{Military Intervention in Nigeria's Politics: Coups, Revolutions or Youth Activism?}

The processes that accompany the manifestations of military punctuations of civilian rule in Nigeria accommodate variables which could qualify it as coups, revolutions or youth activism. The general consensus as depicted by literatures on Nigeria's political and military history embraces and portrays the interventions of the praetorian guards majorly as coups while negating other variables which could question such analysis.

What then is a coup? According to Merriam Webster Dictionary, a coup is a "sudden decisive exercise of force in politics especially the violent overthrow or alteration of an existing government by a small group". It is a "sudden and decisive action, especially one effecting a change of government illegally or by force". In other words, a coup d'état is characterized by "suddenness", "decisiveness", "illegality" and "force" (Toyin, 2015). Therefore, from the criteria of suddenness, decisiveness, illegality and force, one could convincingly assert that of the various processes that led to military interventions in Nigerian politics, only that of July, 1975, December, 1983 and November, 1993 could be uncontrovertibly qualified as coups. The swift process of Murtala Muhammed's ascendency to power was classy and absorbs all the variables of a coup process. The intervention process that propelled General Buhari to the reins of power followed a swift path which started around 2:30am in December $31^{\text {st }}, 1983$ and maturated before noon. It was sudden (between 2:30am and dawn), decisive (important decisions such as the-would-be-leader of the new government was reached before noon), illegal (all interventions are against military ethics and are also treason against the state) and forceful (President Shagari had spent just three months of the four year mandate he was given before being pushed out). In the same vein, Enerst Shonekon being General Babangida's 'step aside' stooge was also muscled out in the same manner described above in November, 1993.

What transpired therefore in the dark hours of January 15, 1966 and July 28, 1966 were but attempted coups, bereaved of suddenness, decisiveness, but forceful and illegal. Though several politicians met their untimely sepulcher in the January, 1966 attempted coup, the ringleaders could not consolidate on their gains for obvious reasons. It therefore took the agreement of the civilians and some high ranking military officers for a civilian backed military dictatorship to be established. Similarly, the July, 1966 intervention cannot be qualified as a coup since it began as a mutiny 
which could only maturate to another military intervention three days after the mutiny. That is to say that the January 15 and July 28 upheavals were attempted coups which though forceful and illegal were not decisive and swift. They are often wrongly classed as coups because their compounding melee climaxed in power change.

Moreso, some variables also fixates military interventions in the milieu of overzealousness on the path of young Nigerian revolutionaries in the army attempting to force restructuring and reforms on the Nigerian polity. For instance, the young and hotheaded majors (in 1966) were frustrated and resentful of the civilian corrupt and inept regime and they hoped to unravel major structural changes through intervention. The Ring leader of the January 15 coup Major Nzeogwu (39 years) was resolute that the process he initiated was not a coup but a revolution to rid the country of "looting, arson, homosexuality, rape, embezzlement, bribery or corruption, obstruction of the revolution, sabotage, subversion, false alarm and assistance to foreign invaders". He hoped to run the government through the "Supreme Council of the Revolution of the Nigerian Armed Forces" and warned foreign countries to "avoid taking sides with the enemies of the revolution and enemies of the people". A semblance of Nzeogwu's revolutionary thought was conspicuous in the Lt. Col. Anthony Nyiam/Major Gideon Orka (38 years) attempted coup of April 22, 1990 which demarcated a line for either resource control (among states) or the severance of the northern region from Nigeria. On this level of analysis, the plotters envisaged themselves as nationalists and revolutionaries who were nostalgic of, and hoped to replicate the feats of military politicians such as Gamel Nasser, Kemal Ataturk, Fidel Castro, Napoleon Bonaparte, Muhammed Ali, etc. However, scholars such as Enor \& Ebaye (2011) have argued that the process of military intervention in politics in itself negates a populist social revolution and forecloses the chances of structural change by the people.

Of the various processes that crystallized in military assumption of power in Nigeria, the July 1966 limbo represents the most conspicuous youth activism in this manner. Here, aggrieved NCOs of northern extraction (all below the ages of 30 years), frustrated by the fact that Lt. Gen Ironsi after the January 1966 abortive coup had failed to try the murderers of their military and civilian leaders, staged a wild 'protest' where hundreds of the 'culprits' (easterners) including Aguiyi Ironsi were brutally murdered (Siollun, 2011). Though the activism of these northern NCOs were rather regionalistic than nationalistic, it does not however, dent the fact that it was a youth's protest against the slow and reactionary policies of the Ironsi regime. This protest-gobad saw a massive shakeup of the Nigerian polity as the northern NCOs held the country to ransom for over 50 hours. It was not until their perceived 
messiah in the person of Lt. Colonel Yakubu Gowon consolidated power that enduring peace could return.

\section{Military Policies and Youth Activism: A Discourse on Nigeria's Repressive Regimes}

Military regimes across the globe are more often than not, tantamount to repression and epitomize blatant negation of fundamental human rights. In the Nigerian political climate, military regimes upon assuming office, first set aside the constitution "to pave way for its replacement by decrees, which are characteristically draconian and anti-human rights" (Animashaun, 2015:61). These decrees which are often intrinsic and inevitable at ridiculing the judiciary have ardent repercussions on freedom, human rights, and all that democracy stands for. With lines of clearly defined sophistry and arsenal of sophisticated weaponry, leaders of military regimes become demigods whose powers and authority, only death can challenge. Under such prevailing quagmire, the citizens are deluded in the false hope and fantasy of reforms, yet, sapped by the draconian and insidious military regimes until they elapse their elasticity limit. The resultant or aftereffect is always resentment and demonstration against the military government and its policies.

Not a single military administration in Nigeria from 1966 to 1999 can be exonerated from the guilt of draconian and obnoxious decrees. However, some regimes were outstanding in their anti-human rights barbarism. As observed by Dada (2013), Yakubu Gowon alone promulgated about a hundred and forty (140) of such decrees which trampled on human rights and civil justice. Examples included Armed Forces and Police (Special Powers) Decree which gave the Inspector General of Police discretional power of arrest and detention; and Federal Military (Supremacy and Enforcement of Powers) Decrees, which completely ousted the jurisdiction of the court in matters within its contemplations. The Murtala/Obasanjo administration was not exempted from such albatross decrees. Under this regime, civil servants were compulsorily retired without due process while the Nigeria Security Organization's (NSO) detention camp at Ita-oko was saturated with arrested dissidents.

General Muhammadu Buhari began his administration by suspending the constitution after which he consolidated on the notoriety of his predecessors. His repressive decrees included the Public Officer (Protection Against False Accusation) Decree which placed the onus of proving innocence on the accused for a publication that brought a public officer to disrepute; the Recovery of Public Property (Special Military Tribunals) Decree and Special Military Tribunal (Miscellaneous Offenses) which both had retroactive effects and imposed heavy penalties; the State Security Detention Decree legalized arrest and detention of persons without trial. Buhari's other obnoxious decrees 
included Public Officers (Special Provision) Decree and Civil Service Commission and other Statutory Body etc. (Removal of Certain Persons from Office) Decree (Dada, 2013:6). It is important to note that successive regimes either modified or blatantly adopted these decrees to concretize their positions of authority.

It is pertinent to clearly state here that the youths dominated the pre1999 Nigeria's political clime. They were the most hit, the most aggrieved and the most ostensive. In fact, it was always the students at various Nigerian universities and most of their socialist inclined professors that frustrated some the most obnoxious military policies through outright protests. During this period, the Nigerian youths in different polytechnics, colleges and universities had given the military governments a 'hunchback' such that every military administration was so much interested in, and even infiltrated student's campus politics. When infiltration failed, the last resort was always force. The situation is best represented in Mihyo's position thus:

Political elite have found students and staff quite an irritant, and the only vocal and publicly dissenting voice. It has not hesitated, often in haste to mobilize and unleash the force of the state repression on the students and faculty (Mihyyo, 1991:4).

When the nefarious Decree No.4, also known as Public Officer (Protection Against False Accusation) Decree was promulgated, the youths in, and outside the university environment protested against it. Young and vibrant journalists, students, workers, politicians and 'ordinary' citizens resented the law. Among the conspicuous youth organizations which called for the immediate abrogation of that decree included the National Association of Nigerian Students (NANS), the Student Press Club of the Polytechnics, Ibadan, students from other universities including (but not limited to) University of Lagos, Yaba College of Technology and Obafemi Awolowo University (Ogbondah, 1988). Consequently, there was an armed intervention in the Ahmadu Bello University, Zaria, resulting in the loss of 15 students' lives. The revolt then spread to other 19 universities in Nigeria. Demonstrations at Universities in Nigeria in May/June 1989 cost 22 students' lives according to official estimates, while unofficial sources estimated the number of deaths to be nearly 100 (Balsvik, 1998). From the statistics presented by Etadon, 14 students were casualties of student unrest between 1976 and 1986 in University of Ibadan. Another 33 students died between 1986 and 1996 in the process of students' violent conflict in Nigeria. 
Table 1: Victims of Students' unrest between 1976 and 1986, UI, Ibadan

\begin{tabular}{|c|c|c|}
\hline S/N & YEAR & NO. OF STUDENTS \\
\hline 1 & 1971 & 1 \\
\hline 2 & 1976 & 4 \\
\hline 3 & 1981 & 4 \\
\hline 4 & 1986 & 5 \\
\hline
\end{tabular}

Source: Etadon, 2013 Ctd. in Akinrole et. al., 2014:363

To further incapacitate university youths, the Ibrahim Babangida dictatorship

...created a panel to investigate the cause of the crisis in Ahhmadu Bello University Zaria which led to the shooting and death of several students by law enforcement agents. The panel accused the lecturers in the University of Not teaching "what they are paid to teach" and recommended that the government should follow up this accusation...The SSS agents, disguised as students, invaded the universities, monitoring teachers and students and filling reports to the authorities. In 1988... without prior warning, Dr. Patrick Wilmot, a political science lecturer at Ahmadu Bello University, Zaria was deported to London by the SSS in violation of his rights and personal security (Ugochukwu, 1997:87).

A number of lecturers in universities of Ibadan and Calabar, inclined to the leftist philosophy and regarded as being unpatriotic on the advice of the NSO were either blacklisted or discharged. Courses that bordered on social contracts, sharpened the students' consciousness, and solidified students' ideology were either modified or disbanded.

Some of the military administrative policies were so irritating, exasperating and directionless that it curled criticism from all and sundry. The military administrators were labeled brain death by some of it critics such as the Song writer, Fela Anikulapo Kuti whose "Government of the Crooks" vituperated thus:

This is my country

Nobody suppose harass me

Police and soldier no go gree,

For my country o

Zombie wan be oga,

How zombie can be oga

Zombie na zombie
This is my country

Nobody is supposed to harass me

But policemen and soldiers won't let it

For my country o

Soldiers want to be the boss

How can soldiers be the boss?

A soldier is a soldier

Source: Eesuola, (2015:85)

In May/June 1989, the Nigerian youths took to the street to register their discontentment of the Babangida's Structural Adjustment Programme (SAP). The SAP protest spilled over from university campuses into the streets. 
Defying the intimidation of the generals, students stormed the streets, demanding the reason for the selective suffering; for while they wallowed in poverty, the first family was in affluence with monies stocked in foreign accounts. The anger of the youths was that while Nigerians had been suffering the effects of SAP, their leaders were quite comfortable. The military government in its routine manner responded by closing down six universities for one session. This was arbitrary and unconstitutional since "education", argued Eboh (1990:28) "is a citizen's right, not rewards for docility". The climax of the whole drama was that the military government was pressured into introducing short welfare packages to create jobs, feed the hungry and ameliorate the transportation situation in the country. 62,000 jobs were to be created in six months while the Works ministry was to provide additional jobs for 10,120 non-graduates, engineers and surveyors within six months (Eboh, 1990:30-31). According to Balsvik (1998), 21 universities were closed down for five months after the anti-SAP demonstration.

When the military government in June, 1993 displayed its age long treachery of prolonging swift transition to civilian rule, the youths were viscous and intransigent in demanding for a civilian government. As reported by Human Rights Watch (1994), a number of students and others were killed in Edo State in reprisal attacks while homes of opposition leaders were bombed by unknown assailants. In the same demonstration in Lagos and other southern cities, soldiers are reported to have killed more than 150 people. The pro-democracy group National Democratic Coalition (NADECO) was declared illegal in the same month (May, 1993) of its foundation. When members of the disbanded Senate threatened to reconvene on a stipulated date, they were arrested and detained for weeks while about 13 of them charged with treason remained incarcerated for nearly two months. As part of the demonstration against the Military government's rascality, the National Union of Petroleum Gas workers (NUPENG) proceeded on industrial action on July 4, 1993. The Abacha junta, hurt by the action resorted to "bribes, threats, arrest, and eventually, when these methods failed, he dissolved the leadership of the oil union and ordered workers back to work". The Labour Minister, reacting to the above incident averred that the government is on a find, fix and finish mission, hence, all voices of opposition will be "exterminated even if they go underground in such a way that history will not remember that they even existed".

As the hub of the demonstration consciousness, the National Union of Teachers (NUT) and the Academic Staff Union of Universities (ASUU) also went on strike. The government however reacted by closing down some universities even before the commencement of the strike action. Protest by students of Obafemi Awolowo University (OAU) was met with brutal attack by armed policemen. In their known modus operandi; 
Many people were savagely beaten with whips and gun butts. Others were locked in unventilated rooms into which teargas canisters were thrown. Many residents were robbed and had their homes and other property vandalized and partially destroyed (Human Right Watch, 1994).

In the University of Benin, students reacted, in August 17, 1993, by joining other civilians in a violent protest and attacks at homes of serving and former government officials. The police responded by assaulting two universities in the city and admitted killing four students. Many female students were raped and the casualty figure was routinely deflated. The military government also arbitrarily arrested and detained hundred of dissidents including Anthony Enahoro, Gani Fawehinmi, Ken Wiwa, etc. It is important to note that:

Detainees have included children as young as ten years of age. At the demonstration of July 18, twenty-eight persons, most of them children under the age of fifteen and some as young as ten years old, were arrested (Human Right Watch, 1994).

The youths throughout the entire debacle of military rule were a nightmare to various military administrations. They were adamant, obstinate, intransigent, and were all out in number to regain their social contract. Armed with the right consciousness that power belongs to the people; and angered by the scenario that "Nigeria was a colony of military generals administered by the rank and file in the military" (Eesuola, 2015:79), the youths sacrificed their lives, happiness and time to wrestle Nigeria from the dungeon the military had left it. Their courage and perseverance depicted patriotism and nationalism. But for the role of the youths, scholars such as Eesuola (2015) believe Nigeria would have still been in the abyss of military dictatorship.

\section{The Enduring Legacies of the Repressive Military Policies in post-1999 Nigerian Youths}

The implications of the Nigerian military draconian regimes on the post $20^{\text {th }}$ century Nigerian youths have manifested in diverse forms and dimensions, with the most conspicuous being on the political environment. The covert and overt state terror perpetrated by the agents of the military regimes was not without attending psychological impact. Brutal and naked force unleashed on innocent and young activists as well as university students culminated in a confluence of divergent cause and effect connections. Amidst the pool of aggrieved youths that 'fought' the military dictators, four categories had subconsciously emerged before the year 1999 when the military capitulated. They were: the Messengers, the Sycophants, the Cowards, and the Faithfuls. 
The Messengers are those who subscribed to the aphorism "if you cannot fight them, join them". This category of youths had either through the horrific experience in their clash with the military "terrorists" or their personal experiences, acquired and mastered enduring skills at unleashing brutality which was very useful to the military intelligence. They were bankrolled and assigned different assignments ranging from orderlies to administrative moles in various government parastatals, agencies and tiers of government. There is every indication that most of the atrocities perpetuated by the military Juntas were neither executed directly by the NSO or the SSS but by the Messengers.

The Sycophants represents a group whose position boomeranged from criticism to hailing of every step and policies advanced by the military governments. This group became the propaganda driving machine who did all it could to portray the military dynasties as infallible. A greater number of membership of this group came from SSS infiltration of Student Union Governments across many Nigerian tertiary institutions. This group soared during the regimes of President Babangida and General Sani Abacha. Both used astronomical amount of money to lure people to do their biddings in the name of "settlement". It is little wonder that the Senate President Iyorchia Ayu was impeached by the Nigerian Senate for opposing moves to extend Babangida's tenure beyond August 27, 1993; and all the political parties in 1998 collapsed their structures for the emergence of General Abacha as a sole candidate for the anticipated general elections.

Figure 1: Showing the Psychological Impact of Repressive Military Policies on the Post 1999 Nigerian Youths

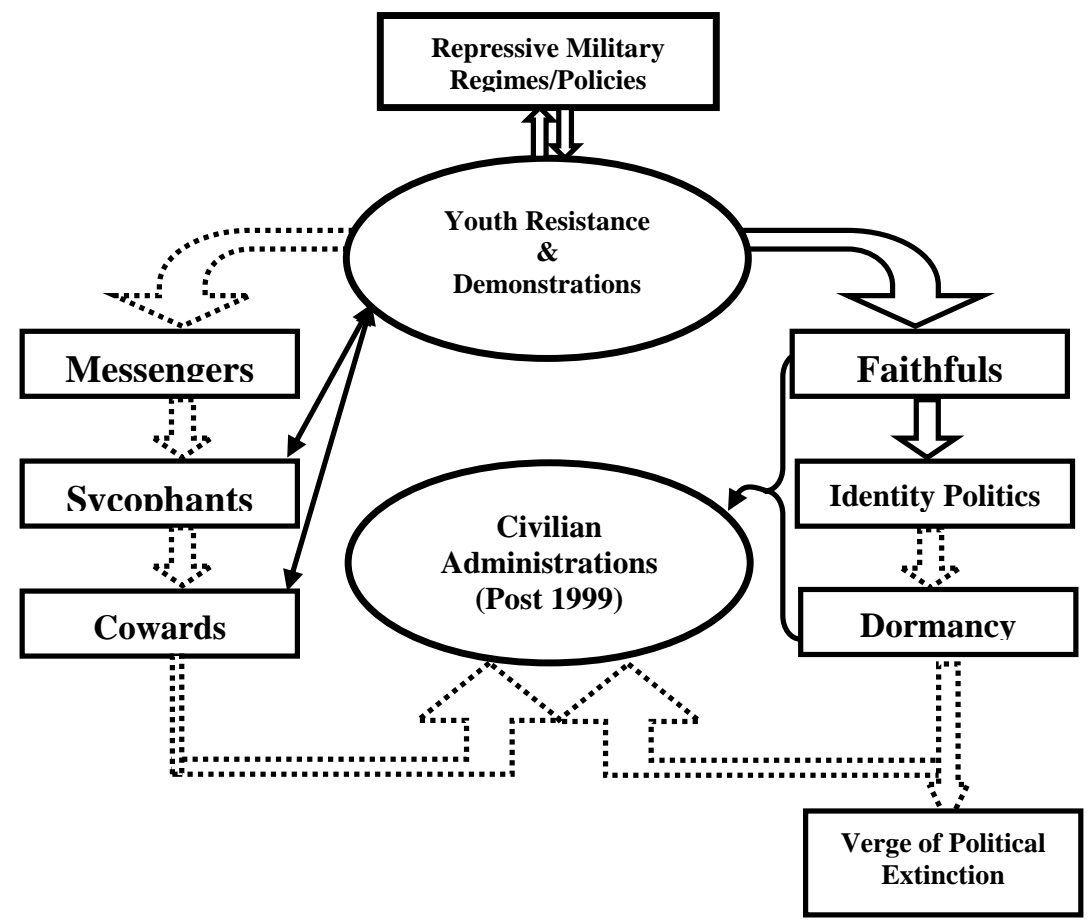


The Cowards were the youths who never summoned the courage and those who could no longer withstand the terrific scenes of the military brutal actions. They were largely indifferent, and mostly apathetic in reacting to situations, even the ones with direct implications on them. They were not resilient and had succumbed to the military's notion of peaceful protest being treasonable and anti-state. Without much fight, for fear of their lives, they accepted the military echelons' position of demigods and were ready to worship them, if need be. As general Abacha became very aggressive, gruesome and unpredictably dangerous, this group multiplied in millions.

The Faithfuls were the ardent, incorruptible and pious group who were ready to lay their lives to wrestle the country from the den of the praetorian guards. Sadly, the composition of this group had diminished in a seemingly direct proportion to Babangida and Abacha autocracies.

In synopsis, the first three groups, that is, Messengers, Sycophants and Cowards have advanced their respective skills in the post $20^{\text {th }}$ century Nigeria's political clime. While the Messengers are now consolidating on their positions in the government, the Sycophants have innovated their realm, skills and technologies with much ado and advanced budgetary allocations from the government. The Ministry of Information and Communication has become so crucial that its budget runs into billions of Naira. The Cowards are exceedingly indifferent, lackadaisical and ill-informed. They are easily manipulated by the Sycophants while they know a pinch of government policies and how it affects them. They perpetually question nothing but go with the bandwagon views on any trending issue. These three groups do not care about the wellbeing of the country, if they are governed well, if their leaders are sincere and are accountable, or if the terms of the social contract are strictly followed. All they are interested in is their personal survival and self-preservation. The Faithfuls, though a handful, had placed so much confidence on the anticipated civilian government such that they washed off their feet from healthy protest and demonstration to keep successive government on toes. While it is difficult to rally this caliber around as in the military era where there was a common enemy, regional, ethnic, tribal and religious differences have triumphed over objective reasoning; this group is thus in the brink of extinction.

\section{Disarticulation}

When in 1999, the military junta of General Abdulsalami Abubakar handed over power to a repented democrat, Olusegun Obasanjo, the nation's economy was in shambles, the military was still on alert with much ado for an opportunity to intervene; the polity was very much fragile, enmeshed in a high level of tension and uncertainty. Thus, amidst eyesores of monumental corruption, human rights violations, dent in electioneering process and political assassinations, the Obasanjo civilian government enjoyed massive 
support because to the Faithfuls, "the worst civilian government is better than the best military dictatorship". The advent of President Umaru Musa Yar'Adua in 2007 signaled hope. His pacification of the Niger Delta region through the famous amnesty programme reshaped the economy while giving the nation a direction. Yar'Adua's subsequent incapacitation and death in 2010 parachuted Dr. Goodluck Jonathan to the helms of affairs as the succeeding president. The Jonathan's administration was marred with monumental corruption. Amidst swelling oil prices, the state treasury was in a flux of depletion while corruption was unofficially 'legalized' (See Ekpo et al, 2016)c. But for the vibrant economy it left and upholding of human rights, his government was on the same level with that of the military regimes in mortgaging the future of Nigerians.

In what the author considers one of the wonders of the $21^{\text {st }}$ century, General Muhammadu Buhari won the 2015 presidential race; but not without series of clearly defined stratagem, subterfuge, and sophistry advanced by his political party. This is more so as the Buhari civilian government has contradicted everything it stood for during its campaign days. The country's economy is in a putrid state as the value of the nation's currency is on a freefall in the global currency exchange market. Imported goods have attained 200$300 \%$ increase in prices. In fact, the nation's economy is on a hyperinflation and the brunt of it all is on the common man. The country's wavering economic and exchange policies have culminated in the collapse of, and massive retrenchment by some firms. While hundreds of Foreign Direct Investments (FDIs) have pulled out, hundreds are reconsidering their decisions to move in. The few establishments operating are downsizing while anxiously waiting for the vacillating government policies to stabilize. Power generation has remained a 'rocket science' while the government has preposterously removed subsidy on fuel without adequate and tangible palliatives. The depressed economy has caused staple foods to become luxuries for the common man; in fact, affording a three square meal recently in some part of the country is a miracle that warrants testimonies. Life has become so difficult that even a deaf and dump Nigerian feels the difference between the present administration and its predecessor. Yet, the Presidency in the 2017 Appropriation Bill, as reported by VanguardNews Online, $\left(24^{\text {th }}\right.$ December, 2016) has proposed $\$ 6.5$ billion for capital expenditure, $\$ 100.8$ million for kitchen equipment, $\$ 967$ million for personal food supply, $\$ 198$ million for buses and SUVs, $\$ 103.9$ million for computers and a monumental $\$ 4.95$ billion for annual maintenance of Aso Rock Villa.

The irony remains that things weren't this bad when the youths protested vehemently against the Babangida's Structural Adjustment Programme for the anger of the youths then was that "while Nigerians had been suffering the effect of SAP, their leaders were quite comfortable" (Eboh, 
1990:30). In fact, the French, Russian and Chinese economies were not this vandalized when the citizens rose up to demand the termination of their social contracts with the handlers of those economies.

Moreso, in Nigeria today, there is a new meaning and definition of "anti-corruption" - an apt replica of the military regimes' anti-corruption jamboree and rhetoric that infuriated the then Nigerian youths. The presidency, its associates, ruling party bigwigs and affiliates, 'top' government officials and friends of the government are saintly and holy. According to President Buhari, the brunt of proving the corruptibility of any of his ministers is on the whistle blowers. This is a semblance of the infamous Decree No.4 (Protection Against False Accusation) which the pre-millennial youths ferociously condemned and energetically protested against. Interestingly, opposition party men that are yet to carpet cross are hunted down on a seemingly premeditated vendetta mission. Anyone that is opposed to the government's policies is hunted down by the state security service (SSS). Just like the pre-1999 years, there is rare room for opposition. Distinguished dissidents such as Nnamdi Kanu of the IPOB are incarcerated in defiance to court orders for their freedom. The camouflage of anti-corruption fight is utilized in caging the judiciary and the opposition. While corruption cases involving the ruling party officials are fought with deodorants, that involving the opposition is fumigated with biological weapons. The days of freedom of information are far gone. The prevailing scenario is best explained by the epigram that one's freedom of speech is sacrosanct but freedom after speech is that not guaranteed. Infact, qualifying the existing order as being "pseudo democratic" will be an understatement.

The teaser therefore is, why has the youths largely remained calm, comfortable, satisfied and lethargic amidst objective conditions for demonstrations? The answer is glaring and is a reminiscent of the Messenger, Sycophants, Cowards, and Faithfuls analogy earlier registered in this work. It is further hinted in Ojo (2008:15) submission that:

...many years of military dictatorship has left some psychological scars in the minds of the generality of the Nigerian populace and this has weakened that inherent disposition of the youths to agitate for change.

Judging by the findings of this work so far, it appears there is no hope for the Nigerian youths in particular and Nigeria at large. A larger percentage of the Nigerian youths have been reduced from their legitimate position of patriots to mere praise singing parrots. Their sense of reason has been clouded by religious, ethnic and regional sentiments. As majority of the Yoruba youths hailed all the moves made by the Obasanjo civilian government, the Niger Delta youths even threatened to "go back to the creeks" in defense of "their son" President Jonathan. Interestingly, millions of Nigerian youths have 
subscribed to the \#ISTANDWITHBUHARI group, while another million are empathetic to it cause of defending the plague of a Buhari government and their quest at portraying it infallible. The truth is, none of the youths after the repressive military regimes are ready to stand with Nigeria. Their conscience, consciousness and nationalistic ideals are poisoned with the effluvium from age long ethnic, religious, and regional sentiments. The youths are now the Messengers of their regional godfathers. They unleash avalanche of propaganda to shape public opinion and wield tribal sentiments when their godfathers are trapped by the law. They have euphemized their cowardice at standing with Nigeria for loyalty to their regional godfathers. Patriotic youths in the Nigerian polity are now a seldom commodity - as rare as oasis in the Kalahari Desert. This situation is not unconnected to the military repressive policies. It could be safe to posit that the above mentioned condition is a legacy of military terrorism against the pre-millennial Nigerian youths. Docility and sycophancy than any other political disease, is now highly communicable and made worse by the low standard of education in the country by which educated illiterates are churned out in their number yearly.

\section{Conclusion: Any Hope for Nigeria?}

The lethargy and dormancy which the post-1999 Nigerian youths have exhibited over issues bothering social contract has become so discomfiting that observers could mistake it for paralysis. When the country's hard earned democracy was at the brink of collapse, following the seizure of power by President Yar'Adua kitchen cabinet upon his incapacitation, and the resulting quagmire which would have seen the spying military takeover power, the youths remained the apologetic onlookers while the 'old boys' strove and successfully restored normalcy. It took the agitations of the NADECO old boys such as Prof. Soyinka for power to be handed over to the then Vice President Dr. Goodluck Jonathan to govern on acting capacity. Similarly, while it dawned on Nigerians that the proposed and subsequently implemented removal of subsidy on petroleum products on January 1, 2012 would hurt them, it took the faces of the old boys as Prof. Soyinka and Pastor Tunde Bakare to organize and escalate the famous \#OCCUPYNIGERIA which forced the Jonathan's government to reconsider the policy.

Unlike the military era, agitations and demonstrations instigated and fronted by the youths have become so rare that one found is considered an anomaly. However, the story is gradually changing. Recently, the popular Nigerian musician Innocent Idibia generally addressed as Tuface had on January $25^{\text {th }}, 2017$, announced a nationwide protest against obnoxious All Progressive Congress (APC) led government. According to him, the planned protest was to be; 
... a call for good governance. A call for urgent explanation into the reckless economic downtown nationwide. A call for a nationwide protest as we say no to the Executive, no to the Legislatures, no to the Judiciary...Y You have all failed us. We the people are tired. We can no longer continue with all of you. All your excuses and mistakes are not funny. We do not wish to continue with a system and government that is not working but afflicting the people. We the people of this country... have now accepted to take the bull by the horn to come out and protest this obnoxious and baseless policies and excuses of the government of the day...

A careful look at this protest call by Idibia shows a vibrant articulation and comprehension of the prevailing disaster of a government led by President Muhammadu Buhari. The objective conditions raised by Mr. Idibia are quite evidenced and legitimate. It is also reflective of the fact that though Nigerian youths remain ostensively docile, they still feel the pains and can articulate them, at least in theory. The unfortunate epilogue is that Mr. Idibia was reduced to, and suffocated with hate speeches, condemnations, rebukes, threats and blackmail. As a youth whose best category the Coward defines, Idibia first postponed the protest date from February $5^{\text {th }}$ to February $6^{\text {th }}$ but later capitulated to pressures by calling off the protest for security reasons.

It appears the youths are recuperating from the psychological amnesia advanced them by successive military regimes; though the recuperation is quite slow and sluggish. The bottom line here is that dormancy should not be interpreted as death and docility should not be perceived as paralysis. All sundry should know that a day will come when the intestine will no longer need the support of the anus to cause constipation. A day will also come when the men in the youths who have 'died' will resurrect and go all out to retrieve their social contract. A day will come when out of strain, excess adrenalin will propel cowards and sycophants into demanding for that which is rightly theirs. This paper thus, is a wakeup call for both policy makers and the youths alike.

\section{References:}

1. Aiyede, E. R. (2015). "Democracy and Security Sector Governance and Military Reform in Nigeria" In Bryden, A \& Chappuis, F. (eds) Learning from West African Experiences in Security Sector Governance. London: Ubiquity Press. Pp-97-116.

2. Ajayi, A. I. (2013). "Military Regimes and Nation Building in Nigeria, 1966-1999". African Journal of History and Culture, Vol.5, No.7 pp.138-142. 
3. Akinrole, O. O. O. et al (2014). "Violent Protests in Private Universities in Nigeria: Implications for Educational Development". European Journal of Social Sciences, Vol.45, No.4, Pp.359-371.

4. Altbach, P. G. \& Clemencic, M. (2014). "Student Activism Remains a Potent Force Worldwide". International Higher Education, No.76.

5. Aluede, O et al (2005). "Student Unrest in Nigerian Universities: Looking Back and Forward". J. Soc. Sci., Vol.10, No.1. Pp.17-22.

6. Animashaun, B. O. (2015). "Human Rights, Governance and the Nigerian Constitution: A Historical Survey". Journal of Humanities and Social Sciences, Vol.17, No.5., Pp.59-64.

7. Balsvik, R. R. (1998). "Student Protests - University and State in Africa 1960-1995”. Forum for Development Studies, No.2, Pp.301325.

8. Brown, C. M. (2013). "Nigerian Political System: An Analysis". International Journal of Humanities and Social Science, Vol.3, No.10. Pp.172-179.

9. Dada, J. A. (2013). "Human Rights Protection in Nigeria: the Past, the Present and Goals for Role Actors for the Future". Journal of Law, Policy and Globalization, Vol.14., Pp.1-14.

10. Eboh, M. P. (1990). "The Anti-SAP Upheaval in Nigeria". Philosophy and Social Action, Vol.16, No.3, Pp.22-32.

11. Eesuola, O. S. (2015). "Role Reversal Protest in Nigeria: Soldiers Still the Boss? A Behaviouralist Inquiry into the Incessant Soldier-Police Violent Conflict in Lagos". AFRREV, Vol.9, No.2, Pp.78-90.

12. Ekpo, C. E. \& Agorye, C. A. (2018) "A (un)Just and (un)Holy War? The Theme of Imagery and Symbolism in the IPOB Secessionist Struggle". International Journal of Management and Social Science, Vol.6, No.6, Pp.28-55.

13. Ekpo, C. E. \& Chime, J. (2016)a. "Africa and the Origin of Democracy: A Reappraisal of the Igbo "Stateless" Society". International Journal in Management and Social Science, Vol.4, Iss.9, Pp.1-10.

14. Ekpo, C. E. \& Chime, J. (2016)b. "Democracy and Revolution as Tools for Nation-Building in Africa”. The Journal of Social Sciences Research, Vol.2, No.8, Pp.152-158.

15. Ekpo, C. E. (2016)d "The Relevance of the NYSC Scheme: Then and Now, What Has Really Changed?" Oyokopa, Batch B, November/December Edition, pp.16-17.

16. Ekpo, C. E. (2017). "Interest, Diffidence, Rigidity and the Challenge of Constitutional Change - The Nigeria's Experience”. Legal Aid Oyo Journal of Legal Issues, Vol.1, No.1, pp.27-34. 
17. Ekpo, C. E; Chime, J. \& Enor, F. N. (2016)c. "The Irony of Nigeria's Fight Against Corruption: An Appraisal of President Muhammadu Buhari's First Eight Months in Office". International Journal of History and Philosophical Research, Vol.4, No.1, Pp.61-73.

18. Elebute, A. (2015). "Issues on the Gagging of Nigerian Press with Obnoxious Law". International Journal of Arts and Humanities, Vol4(1), No.13, Pp.207-223.

19. Enor, F. N. \& Ebaye, S. E. (2011). "Military Coup as a Negation of Social Revolution: the Nigerian Experience". Mediterranean Journal of Social Sciences, Vol.2, No.3. Pp.419-425.

20. Frank, E. O. \& Ukpere, W. I. (2012). "The Impact of Military Rule on Democracy in Nigeria”. J. Soc. Sci., Vol.33, No.3, Pp.285-292.

21. George, O; Shadare, S \& Owoyemi, O. (2012). "Military Intervention in the Nigerian Politics: 'A Timed Bomb' Waiting to Explode? The Vowel of a New Management Elites". International Journal of Business, Humanities and Technology, Vol.2, No.5, Pp.191-198.

22. Harl, S. I. (2014). "The Evolution of Social Protest in Nigeria: The Role of Social Media in the "\#OccupyNigeria" Protest". International Journal on Humanities and Social Science Invention, Vol.3, Issue 9, September. Pp.33-39.

23. Human Right Watch (1994). Nigeria: "The Dawn of a New Dark Age", Vol.6, No.8, October.

24. Huntington, S. P. (1957). The Soldier and the State: The Theory and Politics of Civil Military Relations. Boston: Harvard University Press.

25. Jauhari, A. (2011). "Colonial and Post-Colonial Human Rights Violations in Nigeria". International Journal of Humanities and Social Science, Vol.1, No.5, Pp.53-57.

26. Mihyo, O. P. B. (1991). The Roots of Student Unrest in African Universities. Nairobi: Issa M. Omari.

27. Ngara, C. O. \& Esebonu E. N. (2012). "The Mass Media and the Struggle for Democracy in Africa: The Nigerian Experience". Nordic Journal of African Studies, Vol.21, No.4, Pp.183-198.

28. Nwankwo, B. C; Ocheni, S. \& Atakpa, M. (2012). "A Review of the Contributions of Military Regimes to Social Mobilization in Nigeria, 1966-1996". Journal of Arts, Science and Commerce, Vol.3, Issue3(2), Pp24-32.

29. Ogbondah, C. W. (1988). "Nigerian Press Under Imperialists and Dictators, 1903-1985". A Paper Presented at the International Division of the AEJMC Conference, Oregon, 1988.

30. Ojo, O. S. (2008). "The Role of Youth in Democratic Consolidation in Fragile States: The Nigerian Experience". A Paper Presented at the International Conference on the Nigerian Youth, Political Participation 
and National Development at Mambaya House, Bayero University, Kano, $4^{\text {th }}$ August.

31. Omilusi, M. (2015). "From Civil Rule to Militarized Democracy: Emerging Template for Governance in Nigeria". International Journal for Politics and Good Governance, Vol.6, N0.6.2, Pp.1-20.

32. Siollun, M. (2011). Oil, Politics and Violence: Nigeria's Military Coup Culture. New York: Algora Publishing.

33. Siollun, M. (2013). Soldiers of Fortune: Nigerian Politics from Buhari to Babangida 1983-1993. Abuja: Cassava Republic Press.

34. Toyin, O. S. (2015). “The Impact of Military Coup D'etat on Political Development in Nigeria". International Journal of Business and Social Science, Vol.6, No.10. Pp.194-202.

35. Ugochukwu, B. (1997). "The State Security Service and Human Rights in Nigeria". Third World Legal Studies, Vol.14, No.5, Pp.71-101.

36. Undiyaundeye, U. A. (2011). "Patriotism or Enlightened Self Interest: A Casual Analysis of Nigeria's First Coup D'etat". The Calabar Historical Journal, Vol.5, Nos. 1\&2, December, Pp.131-156.

37. Wilmot, P. F. (1980). Ideology and National Consciousness. Ibadan: Lantern Books. 